\title{
Features and perspectives of transition of Russian economy to technological paradigm: regional aspect
}

\author{
Marina Alekseevna Izmailova \\ Financial University under the Government \\ of the Russian Federation \\ Department of Corporate Finance and Corporate \\ Governance \\ Moscow, Russia \\ m.a.izmailova@mail.ru
}

\author{
Mikhail Iakovlevich Veselovskii \\ University of Technology \\ Department of Management \\ Korolev, Russia \\ consult46@bk.ru
}

\author{
Vera Grigorievna Aleksahina \\ University of Technology \\ Department of Management \\ Korolev, Russia \\ aleksahinavg@ya.ru
}

\begin{abstract}
The article deals with the analysis of Russian economy's condition in the period of digital transformation. The results of the analysis of the dynamics of Russian economy were presented at the national and world level. The assessment of Russian economy was given at the stage of digital economy formation. Recession tendencies of recovering economic growth of the state, decrease of innovative activity and complexity of Russian economy were identified. The list of problems solved within national economy and directions of the state support of transition to new technological paradigm were given.
\end{abstract}

Key words - Russian economy, digital economy, economic growth, innovative activity

\section{INTRODUCTION}

The goal of this article is the analysis of Russian economy`s condition, the determination of tendencies on the stage of digital transformation for building the adequate trajectory of recovering of technological leadership of the country globally.

Importance of the research is dealt with the need for a realistic assessment of the condition of the Russian economy allowing to find main problems and risks of economic development and to identify the ways of increasing of innovative capacity of the country as a factor of sustainability, security and national sovereignty.

\section{MATERIALS AND METHODS (MODEL)}

The research was conducted with methods of statistical, comparative and abstract-logical analysis, formalization, inductive, deductive and general logistic methods. Authors conclusions are based on interpretation of official data of Rosstat, the World Bank, authoritative Russian and international organizations.

\section{RESULTS AND DISCUSSION}

A. Assessment of the Russian economy's condition at the stage of digital economy formation

Analysis of dynamic of Russian economy development in 2007-2016 allowed to find its positive trend particularly noticeable starting in 2013 (fig. 1). There are results of changing in Russia's global rating position in the field of doing business (DB), the level of innovation in the country (GII) and economic competitiveness indicators (GCI) for 2007-2016 on the figure 1 . The highest positive changes connected with indicators of doing business - since 2011 the declining trend characteristic for the period 2006-2011 has been reversed [1]. 


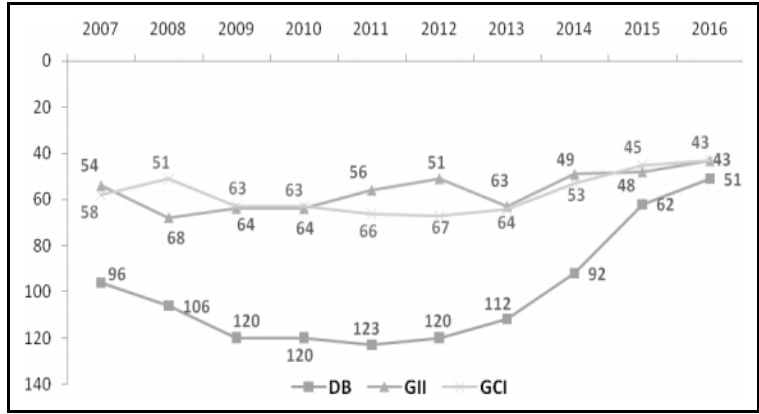

DB - "Doing Business" rating, GII - “Global Innovation Index" rating, GCI - "Global Competitiveness Index" rating

Source: «Doing Business» ${ }^{1}$, «Global Innovation Index» ${ }^{2}$, «Global Competitiveness Index» ${ }^{3}$

Fig. 1. Dynamics of Russia`s positions in the global rankings

According to experts [2], the recovery growth of the Russia economy demonstrated downtrend at the end of 2017. As follows from the data of Rosstat on economic activity in 2017 only indicators of real salary appeared in a relatively good position in October: their growth lowed only to $4.3 \%$ from $4.4 \%$ in September and made $3 \%$ for 10 months. The real income of Russians show the negative dynamics - in October it decreased by $1.3 \%$ in annual terms but this decrease was $0.3 \%$ (fig. 2) in previous August-September and economists had a hope of stabilization.

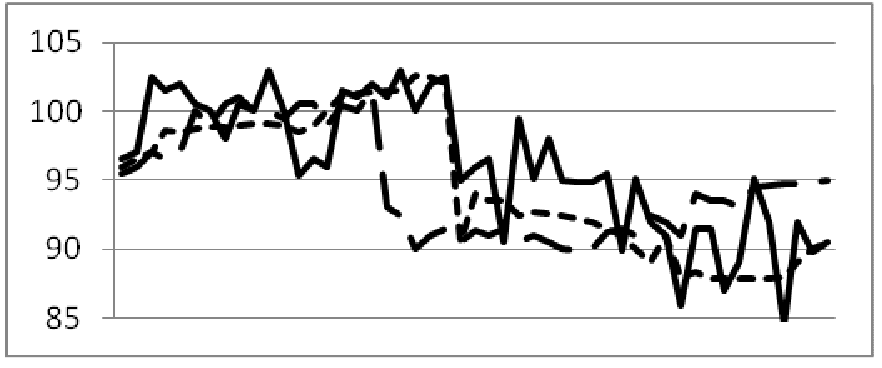

2013 2017

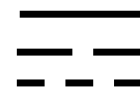

Real disposable income Real salary Real personal consumption expenditures

Source: Rosstat ${ }^{4}$

Fig.2. Disposable income, salary and personal consumption expenditures in real terms (excepting seasonal factor, $2014=100 \%$ )

Moreover, the real incomes are declining for the fourth year consecutively: according to calculations of Fitch Ratings

${ }^{1}$ Doing Business 2007-2016 - URL: http://www.doingbusiness.org/ (Access date 10.11.2017)

${ }^{2}$ Global Innovation Index 2007-2016 - URL:

https://www.globalinnovationindex.org/ (Access date 10.11.2017)

${ }^{3}$ Global Competitiveness Index 2007-2016 - URL:

http://reports.weforum.org/global-compet-itiveness-report-2015-2016/

(Access date 10.11.2017)

${ }^{4}$ http://www.gks.ru/ (Access date: 10.11.2017) they have been decreased by $11 \%$ since 2013 . The Ministry of Economic Development of the Russian Federation has raised the prediction of annual growth of real income from 1 to $1.2 \%$ in August 2017. Reduction of income constrains the consumer demand. Retail turnover counting base effect is also disappointing: it slowed down to $3 \%$ and there is $3.1 \%$ in September. Construction industry isn`t encouraging either: there were reduction by $3.1 \%$ in October and the growth was on $0.1 \%$ in September. Investment growth which government set their hopes on slowed down on $3.4 \%$ in the third quarter of 2017 and on $6.3 \%$ in the second quarter. It got slowdown in a long-term: there were $4.8 \%$ in the first six months and it had been made $4.2 \%$ for nine months. In general, the Ministry of Economic Development of the Russian Federation predicts investment growth on $4.1 \%$ in 2017 and expects significant growth on $4.7 \%$ in 2018. The companies profit growth is being decreased and corporate lending (fig. 3) and business activity is not being increased significantly.

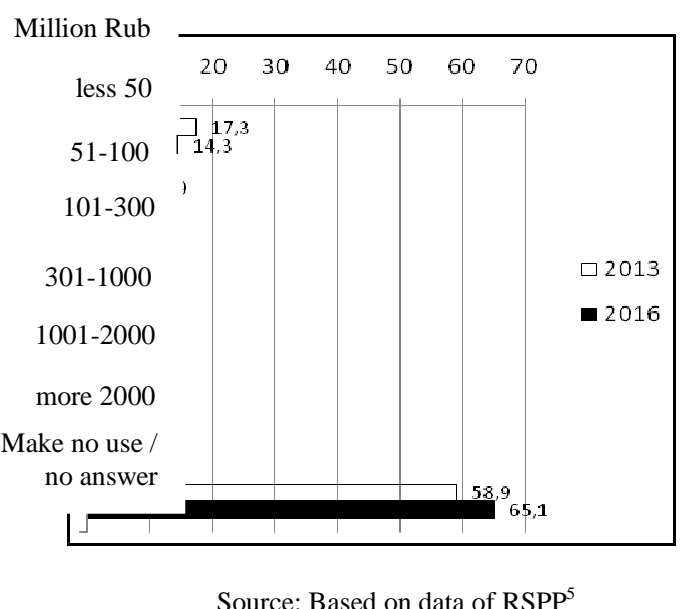

Fig.3. Loan size for the financing of investment projects, $\%$

Experts` opinion about Russian industry concurs on acceptance of stopping the growth and absence of any necessary resources. The GDP was grown on $1.6 \%$ in annual terms in January-September 2017 and prediction of Ministry of Economic Development was $1.8 \%$. According to results of the III quarter the economic growth was slowed down to $1.8 \%$ - industry returned to stagnation. The termination of recovery the growth of Russian economy is admitted by administration of the Central Bank of Russia [3] considering that national economy is growing now at rates close to potential taking into account the structure of economy and its productivity. In case of reforms implementation the growth of GDP can be reached $3-4 \%$. The growth rate of GDP is supposed to be closer to low edge of the forecast interval of the Central Bank (1.7\%-2.2\%) in 2017.

5 Doklad o sostoianii delovogo klimata v Rossii v 2016 godu [Condition of Russia`s business climate report]. - URL http://media.rspp.ru/document/1/f/9/f9c2ca5f8cd104f8d5d40f2a7b50fced.pdf (Access date: 10.11.2017) 
The Ministry of Economic Development of the Russian Federation avers more optimistic position. They aren`t going to reconsider their forecast of GDP growth in 2017 as it is $2.1 \%$ and counts upon the economic growth to be exceeded $2 \%$ in the IV quarter.

Only several industries provide the GDP growth in the IIIII quarters of 2017. In the first place, more standard and homogeneous industries have being grown: finance, retail and wholesale, manufacturing industry. In the II quarter the acceleration was been due to short-term factors - the rise of oil prices, strengthening of the ruble and increasing of government investment in such projects as the Kerch bridge, gas pipeline "Power of Siberia" and construction of facilities to FIFA World Cup. By the middle of 2017 these factors have been exhausted but, nevertheless, the implementation of government projects will be continued and investment will be saved for these purposes. In addition, the mortgage lending will partly support the growth, due to reduction of interest rate car sales are increased for government support and reduction of interest rate, the support can also be provided with the growth of oil price.

Analysis of innovative activity of Russian companies has been shown their sudden gap from their global competitors. Thus, according to OECD, in absolute terms Research and Development expenses of industrial enterprises in China and the USA [4] is almost 30 times higher than amount of costs of Russian industry (fig.4).

In this case, according to "Russian Venture Company" 6 the majority of Russian companies (more 58\%) making technological innovations still prefer to buy final technologies and technological equipment and only $15 \%$ of these companies order or develop being used technological decisions independently.

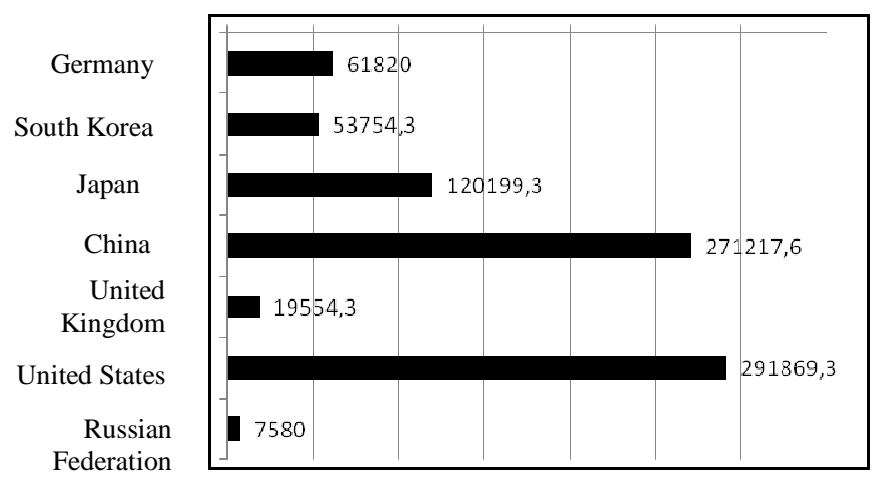

Source: based on OECD data?

Fig.4. R\&D expenses of industrial enterprises, millions of dollars (in constant prices), 2015

\footnotetext{
6 http://www.rvc.ru/ (дата обращения: 15.11.2017)

7 Boosting Productivity in Russia. OECD Economics Department Working Papers N1189. - URL http://oecdru.org/zip/5js4w26114r2.pdf (Access date: 15.12.2017)
}

An observing decrease of Russia`s economic complexity appearing in declining of diversification level of produced products in the country reflects occurring offset of the Russia`s export structure of low complexity, in 2015 the share of these production was $82 \%$ in the structure of export. However, if we pay attention to the share of high-tech products in the total export of the country Russia`s lagging compared with such countries as France, South Korea and China is considerable - but it isn`t so critical - $13.8 \%$ instead of $26.8 \%, 26.8 \%$ and $25.8 \%$ respectively (fig. 5 ).

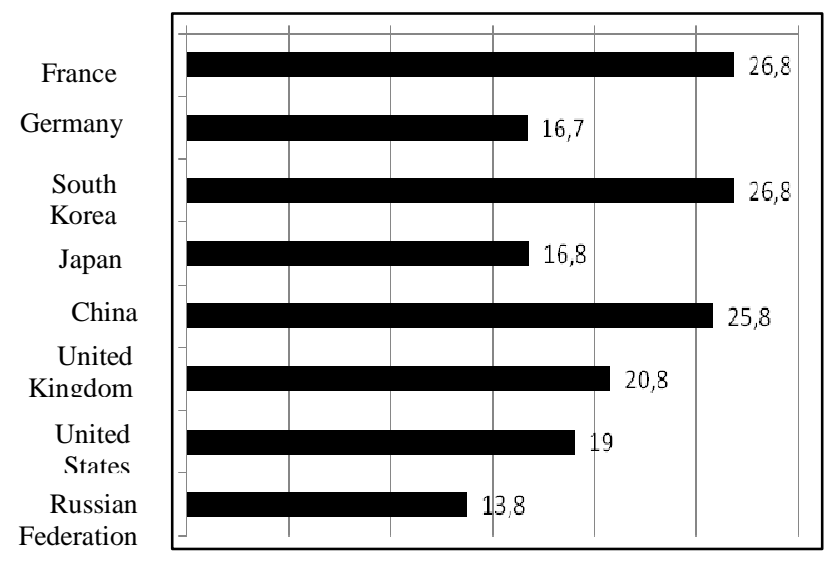

Source: based on The World Bank data ${ }^{8}$

Fig.5. Share of high-tech exports in the total of production export, \%, 2015

Therefore, we can confirm Russia to start the solution of one of the most ambitious tasks - to enter in the TOP-10 of the largest technological countries to 2035 in the condition of interruption the economy growth, low innovative activity.

B. National benchmarks of technological development of Russia's regions

Global experience proves the main instrument of developing innovations to have been science parks infrastructure for several decade. The growth of the innovation component depends on the number of scientific and technological centers in the regions. We analyses [10] three perspective regional business areas according to version of Association of Innovative Regions of Russia.

The first should be noted Technopark of Novosibirsk Academgorodok (Academpark) which has membership in the European Business and Innovation Centre Network cooperating together about 250 science parks, business incubators and venture centers all over the world.

The immensity of science park's activity is confirmed by the following figures: the share of Akadempark is $21 \%$ of all build areas from 12 science parks have been built with government programme, $22 \%$ of residents, $24 \%$ of residents total revenue. There is the lowest share of federal funds - only $21 \%$ - in the structure of Akadempark`s investment compared with science parks of other cities. The planned investment amounts 11.6 billion rubles, the project implementation period - from 2005 to the present time.

\footnotetext{
${ }^{8}$ http://www.vsemirnyjbank.org/ru/country/russia (Access date: 17.12.2017)
} 
One the latest science park's innovation is an opening of the Co-working center "Boiling Point" of Agency for Strategic Initiatives. It is the multifunctioning space for brain storms, conferences, foresights and experts sessions, discussion of the best education practices. This communicative platform is proved the high attractiveness for global experts.

Science park was created to transform science developments in industrial technologies and to build the infrastructure for successful functioning of the innovative enterprises and the growth of new companies. New objects of engineer, transport, housing infrastructure and office and laboratory facilities have been built for resident companies. Centers have been equipped with the latest technological equipment.

Due to the project of Novosibirsk Academgorodok there was formed the platform where innovative business develops, mobilizes investment and builds long-term plans. Besides there were formed technological infrastructure letting entrepreneurs to develop new products without capital expenses. Science park accumulated 112 resident companies the quantities of employees amounted to 4875 people and total revenue reached 13648 million rubles.

As development barriers should be accepted lack of infrastructure in research and development in the field of biotechnologies, nanotechnologies and new materials. The resident companies can`t mobilize investment in the projects. Besides the system of project management for interaction with universities and institutes of Siberian Branch of the RAS doesn't work. Start-up companies aren't informed enough and need events contributing the promotion of ideas and useful contacts.

Innovative territorial center "INO Tomsk" is rather perspective united 50 instruments of federal industrial, economic, innovative and social policy. Amount of investment will be about 250 billion rubles where $65 \%$ is non-budgetary funds in the project by 2020. The industry of Tomsk region has been increased almost on $14 \%$ but manufacturing industry has been increased on $60 \%$ for the last five years. There have been created six clusters in the field of nuclear technologies, petrochemistry, forest industry, renewable natural resources, pharmaceuticals and medical technology, IT and hard-torecover natural resources in the region. Number of innovative products have been invented with the support of the Ministry of Economic Development of the Russian Federation. Software for radiocommunications is used for the 2014 FIFA World Cup Brazil and for Facebook company. In addition, hardware being developed by Tomsk companies is bought by the world golf clubs and meteorological observing stations network. The term of project implementation is 2015-2020.

The goal of INO Tomsk is to create competitive center accumulating industrial enterprises, high professional personnel and perspective technological base. As measurable results it should be noted the preparation of project and estimate documentation for priority capital construction projects and integrated transport infrastructure development. A new model of economic growth has made a significant contribution to the gross regional product, organized a network of integrated urban areas, increased transport accessibility of agglomeration. Besides the conditions for progressive development of professional employment structure within the conception where there is demand of real economy sector on professional competencies and other relevant suggestions from scientific and educational park. Due to "INO Tomsk" specialists will adopt complex of advanced developments to make the science and education progressive and innovative in the region.

The third science park "Zhygulevsky Dolina" was created to modernize the regional economy, to reduce monodependence on Tolyatti in Samara region. The investment will amount 5771.45 million rubles. The term of implementation is from 2010 to present time.

The most important results are next. Project organizers created science park facilities in high-tech. There were partnership base and residents. Innovative ecosystem concentrate the efforts of all elements of regional innovation. Due to office and laboratory and production facilities rent, hotel services, outsourcing services and restaurant the science park was commercialized.

In 2016 "Zhygulevsky Dolina" became the first in the category of business incubators according to the results of RBC, UBI Global and NRU HSE ratings. Science park paid 512.73 million rubles taxes at the end of the year. Here 155 residents work and 1672 jobs were produced.

The development barriers are insufficient funds for engineering infrastructure building on open spaces of science park with increasing costs for the operation of real estate. Besides science park residents don't have tax preference.

C. Perspectives for involving Russian regions in the digitalization of economy

In the conditions of global technologization configuration of Russian economy is surfaced its moderation. To make a digital economy in Russia is on digital development of regions. (= We consider to make a digital economy in Russia possible for digital development of regions).

Each region should be involved into the implementation of program "Digital economy of the Russian Federation" (approved Order of the government of the Russian Federation from 28.07.2017 № 1632-p) ${ }^{9}$ (as it was said - Program), during independently determining its place in it and according to (based on) its specifics and its competencies. Nowadays the Program contains only those chapters that are necessary in general to create conditions for the development of the digital economy in the country. These conditions will provide development of the whole complex of industrial information transformational processes: there will be the main effect from usage of digital technologies in the agriculture for the agricultural regions; "industry 4.0 " for industrial regions. The regions having abilities for development of the digital infrastructure will be efficient the building of the data centers and development of fiber optic communications etc.

\section{9}

http://static.government.ru/media/files/9gFM4FHj4PsB79I5v7yLVuPgu4bvR 7M0.pdf (Access date: 23.12.2017) 
It should be noticed the perspective measure of maximum involvement of the regions in the digitalization of the economy to be considered the addition to the Program with such industrial directions as "smart city" and state governance, which was planned at the initial stage of its development. These measures would be able to bring to the Program applied importance to the regions that could not determine accurate scope of work on the direction "smart city" and usage of digital technologies in state governance.

Nevertheless, the definition of work mechanisms of interaction of the center and regions has important value for implementation of the Program that would be involved the participants in general process. It is necessary to refuse from any typical and standard documents and to support becoming of technological interfaces. On the one hand, it provides the certain autonomy for the subjects and, on the other hand, involves it in a single ecosystem. This should be also applied to state information systems, and structuring of the subjects in the implementation of the program.

The finance guarantee of the Program is the next important task the solution which will determine the cost of each event and the whole Program what amount of funds will be invested by the government and commercial organizations participating in the Program implementation.

It should be noted that the implementation of the Program can not be a single implementer with regard to the Program management system. It is following the need of development of mechanism of active interaction between centers of competence, expert working groups with representatives of business, the scientific community, public organizations that work on the platform of ANO "Data economy". This interaction is taken into account. interests of all participants of the market not only separated implementers but also wide range of interests. The ability to compete within Program implementation will allow to remove all blocking factors for the development of digital technologies and to wide abilities for commerce organizations and government to implement projects including public and private partnership.

\section{CONCLUSION}

Assessment of existing economic situation in Russia shows the further lagging of innovative and technological development from global countries threatens the whole set of risks affecting the structure of the economic system, human capital and labour market, the governance system of modernization of the national economy.

Technological innovations for Russia means not only the formation of new sectors but deep technological and organizational changes in traditional industries in these circumstances [8]. Traditional industries of Russian economy will have to solve the problems in the nearest $10-15$ years:

holding competitive positions on national and global markets;

increasing productivity and fast modernization (including renew of capital assets); adaptation to fast distribution of breaking industrial technologies;

deep transformation of economic agents` business models to be the suppliers not only physical goods and services, but digital products (working with information and data is starting to take a special place in these business models);

low level of activity of industrial companies in the implementation of innovation, orientation its activity mostly on the domestic market [9].

Named problems are typical for the whole Russian economy not only for its basis sectors thus it has definite specific in different industries.

Therefore, according to the existing structure of Russian economy, nowadays development level of national innovative system and complex of risks we consider that country`s transition to the new economic, industrial and technological paradigm will be depended on coordinated implementation of measures in a number of areas. There should be the following: technological modernization of traditional for Russian economy industries, development of new high-tech sectors and the providing the country`s entry into new markets, restart the system of governance of $\mathrm{R} \& \mathrm{D}$, reorganization of development institution, measures for achieving the new quality of human capital and an adequate labour market organization, total / transparent "digitalization" of real economy.

\section{References}

[1] Nureev R.M., Simakovsky S.A. Sravnitel'nyi analiz innovatsionnoi aktivnosti rossiiskikh regionov [Comparative analysus of innovative activity of Russia`s regions]. TERRA ECONOMICUS. 2017. v. 15. no.1. pp. 130-147.

[2] Vosstanovitel'nyi rost rossiiskoi ekonomiki zavershaetsia [The recovery growth of the Russian economy is coming to an end]. URL: https://www.vedomosti.ru/economics/articles/2017/11/21/742450ekonomika-

vidihaetsya?utm_campaign $=25112017 \& u$ tm_content $=14073748897432$ 2\&utm_medium=email\&utm_source=newsletter

[3] Monetary Policy Report. 2017. No 3 (September). 71p.

[4] Hermann M., Pentek T., and Otto B., Design Principles for Industrie 4.0 Scenarios, The 49th Hawaii International Conference on System Sciences, 2016, pp. 3928-3937.

[5] Manufactoring industry in Russia. 2016: Russian St.Yearbook. Rosstat. Moscow. 2016. 347p.

[6] Gorokhova A.E. and Sekerin V.D., Growth of the Russian Industrial Companies Efficiency at Transformation of National Innovative System. In Loster, T., Pavelka, T. (Eds.), The 10th International Days of Statistics and Economics, 2016, pp. 494-503.

[7] Westerman G., Bonnet D. and McAfee A., Leading Digital: Turning Technology into Business Transformation// Harvard Business Review Press, 2014, 292 p.

[8] G. Schuh, T. Potente, C. Wesch-Ponte, A.R. Weber, J.-P. Prote, Collaboration Mechanisms to Increase Productivity in the Context of Industrie 4.0, Procedia CIRP. Vol. 19, 2014, pp. 51-56.

[9] Novaia tekhnologicheskaia revoliutsiia: vyzovy i vozmozhnosti dlia Rossii: ekspertno-analiticheskii doklad [New technological revolution: challenges and opportunities for Russia: expert and analytical report]. Under the supervision V.N. Kniaginina. Moscow. 2017. URL: https://www.csr.ru/wp-content/uploads/2017/10/novayatehnologicheskaya-revolutsiya-2017-10-13.pdf.

[10] Voishcheva M. Tekhnoparki dlia innovatsii [Science parks and innovations]. Strategiia. 2017. No 3(28). pp. 46-48. 